\title{
Ketahanan Pangan Rumah Tangga Petani Selama Pandemi Covid-19 (Studi pada Kelompok Tani Kenanga Mulya Desa Langon)
}

\author{
Hafidh Irfansyah ${ }^{1)^{*}}$, Farida Rahmawati ${ }^{2)}$ \\ 1)2) Economics and Development Study, Universitas Negeri Malang, Malang, Indonesia
}

*E-mail corresponding author: irfanhafidh2@gmail.com

Received: 30-08-2021;

Accepted: 08-10-2021;

Available online: 31-10-2021

\section{Ecoplan}

Vol. 4 No. 2, Oktober 2021, hlm 111-121

\section{ISSN p: 2620-6102 e: $2615-5575$}

Keywords: Food security, Covid-19 pandemic
Abstract - This study aims to determine the level of food security of farmer households in the Kenanga Mulya farmer group, Langon Village, Ponggok District, Blitar Regency before and during the Covid-19 pandemic by analyzing the effect of the number of family members, age, income, food expenditure, and land area. The population in this study includes all members of the Kenanga Mulya farmer group, with the number of samples used in this study as many as 35 people. The data used in this study are primary data and secondary data. Preliminary data were obtained from observations and questionnaires. In contrast, secondary data were obtained from government online publications through the Central Statistics Agency (BPS) of Blitar Regency, Blitar Regency in Figures for 20192021, East Java Industry and Trade Office, and Information Systems for Availability and Price Development. East Java staples. Using multiple linear regression analysis techniques, this study shows that before the pandemic, income, food expenditure, and land area variables had a significant effect on food security of farmer households, the variable number of family members and age had no significant impact on farmer household food security. Meanwhile, during the pandemic, food expenditure variables and the land area had a substantial effect on the food security of farmers' households; the variables of the number of family members, age, and income did not significantly affect the food security of farmers' homes.

\begin{abstract}
Abstrak - Penelitian ini bertujuan untuk mengetahui tingkat ketahanan pangan rumah tangga petani pada kelompok tani Kenanga Mulya, Desa Langon, Kecamatan Ponggok, Kabupaten Blitar sebelum dan selama pandemi Covid- 19 dengan menganalisis pengaruh jumlah anggota keluarga, usia, pendapatan, pengeluaran pangan, serta luas lahan terhadap tingkat ketahanan pangan rumah tangga petani pada kelompok tani Kenanga Mulya, Desa Langon, Kecamatan Ponggok, Kabupaten Blitar. Populasi dalam penelitian ini mencakup seluruh anggota kelompok tani Kenanga Mulya dengan jumlah sampel yang digunakan dalam penelitian ini sebanyak 35 orang. Data yang digunakan dalam penelitian ini berupa data primer dan data sekunder. Data primer diperoleh dari observasi serta kuesioner, sedangkan data sekunder diperoleh dari publikasi online pemerintah melalui website Badan Pusat Statistik (BPS) Kabupaten Blitar, Kabupaten Blitar Dalam Angka Tahun 2019-2021, Dinas Perindustrian dan Perdagangan Jawa Timur, dan Sistem Informasi Ketersediaan dan Perkembangan Harga Bahan Pokok Jawa Timur. Dengan menggunakan Teknik analisis regresi linier berganda, penelitian ini menunjukkan bahwa sebelum adanya pandemi variabel pendapatan, pengeluaran pangan, dan luas lahan berpengaruh signifikan terhadap ketahanan pangan rumah tangga petani, variabel jumlah anggota keluarga dan usia berpengaruh tidak signifikan terhadap ketahanan pangan rumah tangga petani. Sedangkan selama pandemi variabel pengeluaran pangan dan luas lahan berpengaruh signifikan terhadap ketahanan pangan rumah tangga petani, variabel jumlah anggota keluarga, usia, dan pendapatan berpengaruh tidak signifikan terhadap ketahanan pangan rumah tangga petani.
\end{abstract}

Kata Kunci : Ketahanan pangan, pandemi Covid-19 


\section{PENDAHULUAN}

Pengertian ketahanan pangan tidak terlepas dari UU No. 1. 18/2012 Tentang Ketahanan Pangan. Menurut undang-undang tersebut, ketahanan pangan adalah "keadaan negara untuk menyediakan pangan bagi perseorangan, yang tercermin dari ketersediaan pangan yang cukup dalam jumlah dan mutu, aman, beragam, bergizi, adil dan terjangkau, serta tidak bertentangan dengan agama, kepercayaan , dan budaya masyarakat agar dapat hidup sehat, aktif dan produktif secara berkelanjutan".(Undang-undang republik indonesia nomor 18 tahun 2012 tentang pangan, 2012).

Pada bulan Maret 2020 pandemi mulai terjadi di Indonesia, dampak yang cukup besar akibat adanya pandemi ini menyebabkan lumpuhnya sektor-sektor ekonomi seperti pertanian. Tidak hanya di Indonesia, negara lain juga merasakan dampak yang sama akibat adanya pandemi ini. Meningkatnya kasus Covid-19 di Kabupaten Blitar telah menyebabkan perlambatan di berbagai kegiatan perekonomian. Apalagi, dengan berlakunya Kebijakan PSBB (Pembatasan sosial berskala besar), Kemudian hal tersebut akan memicu terhentinya aktivitas Ekonomi akibat adanya Wabah Covid-19. Kabupaten Blitar mencatat rekor tertinggi di wilayah kabupaten se-jawa timur. Jumlah kasus positif Covid-19 di Kabupaten Blitar mencapai 1.821 jiwa, sebanyak 1.559 pasien sembuh, dan sebanyak 131 kasus meninggal pada bulan Desember 2020 (Anonim, 2020).

Sektor pertanian berpengaruh langsung terhadap ketahanan pangan. Pertanian merupakan proses pertumbuhan tanaman pangan yang didasarkan atas proses produksi. (Utari and Zulfaridatulyaqin, 2020). Akibat adanya pandemi ini, ketahanan pangan di Kabupaten Blitar terganggu dengan ditandai luas lahan panen padi di Kabupaten Blitar mengalami penurunan. Luas lahan panen padi pada tahun 2020 sebesar 34.794,97 hektar atau mengalami penurunan sekitar 1.398,97 hektar (3,86\%) dibandingkan tahun 2019 yang mencapai 36.193,94 hektar. Sedangkan pada tahun 2019 mengalami peningkatan sekitar 4.192,94 hektar atau sebesar 36.193,94 hektar dibandingkan tahun 2018 yang hanya sebesar 32.001,00 hektar. (Badan Pusat Statistik Kabupaten Blitar, 2020). Menurunnya luas lahan panen berakibat dengan menurunnya produksi padi. Beras merupakan makanan yang biasanya dijadikan makanan pokok penduduk Indonesia. Beras merupakan produk olahan yang berasal dari hasil pertanian yaitu padi. Produksi padi di Kabupaten Blitar menurun akibat dari menunrunnya luas lahan panen. Produksi padi di Kabupaten Blitar pada tahun 2020 sekitar $196.847,53$ ton atau mengalami penurunan sebesar $27.179,66$ ton $(12,13 \%)$ dibandingkan pada tahun 2019 yang sebesar 224.027,19 ton. Sedangkan pada tahun 2019 produksi padi mengalamai peningkatan sekitar 12.762,19 ton atau sebesar 224.027,19 ton dibandingkan tahun 2018 yang hanya sebesar $211.265,00$ ton.

Selama pandemi kebutuhan akan pangan sangatlah dibutuhkan. Harga bahan pokok di Kabupaten Blitar mengalami kenaikan dari tahun 2019 ketahun 2020. Sedangkan pada tahun 2018 ketahun 2019 harga bahan pokok cenderung tetap dan Ini menandakan bahwa pandemi membawa dampak terhadap naiknya harga bahan pokok. Hal ini disebabkan berkurangnya luas lahan yang dipanen, sehingga mengakibatkan berkurangnya hasil panen. Beberapa penelitian terkait kondisi ketahanan pangan di suatu daerah, terutama yang berkaitan dengan faktor-faktor yang mempengaruhi tingkat ketahanan pangan rumah tangga petani telah dilakukan oleh (Ni Putu, Dwi, dan gede, 2021) dengan menggunakan regresi linier berganda menunjukkan bahwa selama pandemi Covid-19 variabel pendapatan, pengeluaran pangan, dan harga beras berpengaruh signifikan terhadap tingkat ketahanan pangan rumah tangga petani. Penelitian selanjutnya dilakukan oleh (Wahyu dan Yuli, 2020) yang menunjukkan bahwa variabel pendapatan berpengaruh signifkan terhadap tingkat ketahanan pangan rumah tangga petani. Dengan naiknya harga bahan pokok, tentu masyarakat akan khawatir dengan ancaman kerawanan pangan di masa pandemi Covid-19. Salah satu yang terdampak adalah anggota kelompok tani Kenanga Mulya di Desa Langon, Kecamatan Ponggok Kabupaten Blitar. Sebagian besar masyarakat di Desa Langon berprofesi sebagai petani, sehingga pendapatan mereka tidak menentu atau tergantung dari hasil panen. Oleh karena itu, penulis perlu menganalisis status ketahanan pangan rumah tangga petani sebelum dan selama pandemi untuk mencerminkan situasi nyata masyarakat, yang terkait langsung dengan pemenuhan kebutuhan dasar keluarga.

\section{TINJAUAN PUSTAKA}

\section{Teori Ketahanan Pangan}

Menurut Darwanto (2005) dalam (Pasaribu, 2008) menggarisbawahi bahwa ketahanan pangan sangat bergantung pada aksesibilitas stok beras yang dapat diberikan secara luas. Beras dapat disebut sebagai barang sumber karena barang berikutnya $(\mathrm{Q})$ digunakan untuk memenuhi kebutuhan penggunaan keluarga pembuat atau petani (C) dan sisanya ditawarkan ke pasar (M). Secara numerik, penunjukan dapat dirinci sebagai: 


$$
\mathrm{Q}=\mathrm{C}+\mathrm{M}
$$

\section{Teori Ketersediaan Pangan}

Aksesibilitas pangan adalah aksesibilitas pangan dalam jumlah yang memadai yang dilindungi dan bergizi bagi semua individu di suatu negara, baik mulai dari kreasi sendiri, impor, simpanan pangan atau bantuan pangan. Ketersediaan jenis makanan ini harus mempertimbangkan makanan yang cukup, yang ditandai dengan jumlah kalori yang dibutuhkan untuk kehidupan yang berfungsi dan padat. (Priswanti, 2004). Pasokan makanan dalam keluarga mempengaruhi jumlah penerimaan makanan anggota keluarga. Semakin baik persediaan makanan Keluarga dapat memenuhi setiap kebutuhan gizi.

Aksesibilitas dan Keanekaragaman Pemanfaatan Pangan Lainnya disebabkan oleh variabel-variabel berikut: (1) Kondisi atau keadaan wilayah sistem biologi, faktor ini menggambarkan jenis makanan yang dapat diakses secara lokal (2) Faktor sosial dan sosial seperti pola makan dan informasi tentang Makanan dan komponen yang berbeda (3) dukungan transportasi kantor) untuk menjamin kelancaran penyebaran makanan (4) Kesenjangan kemampuan memperoleh makanan karena alasan berikut Perbedaan daya beli kelompok masyarakat. (Suryana, Nia Kurniaish, Said Usman \& Ariani, 2014).

\section{Teori Keynes}

Seperti yang ditunjukkan oleh Keynes, keadaan makroekonomi terjadi dengan apa yang menimpa permintaan sosial total ketika permintaan total melampaui total penawaran (atau hasil terakhir selama periode ini), hal tersebut mengakibatkan akan ada keadaan "kurangnya produksi" (Case, 2008). : 172). Permintaan agregat adalah jumlah uang tunai yang dihabiskan oleh semua tingkat masyarakat untuk membeli barang dan jasa dalam satu tahun. Dalam perekonomian tertutup, permintaan agregat terdiri dari 3 komponen: 1) Pengeluaran pangan oleh Keluarga (C) 2) Penggunaan investasi oleh Perusahaan (I) 3) Pengeluaran Pemerintah (G), Otoritas publik dapat mempengaruhi permintaan agregat secara langsung melalui pengeluaran pemerintah dan dalam jalan memutar langsung pada pengeluaran penggunaan dan pengeluaran usaha. Bila direncanakan adalah sebagai berikut:

$$
\mathrm{Z}=\mathrm{C}+\mathrm{I}+\mathrm{G}
$$

\section{METODE PENELITIAN}

Metode yang digunakan dalam penelitian ini adalah menggunakan metode penelitian deskriptif kuantitatif. Jenis data yang digunakan dalam penelitian ini adalah data primer dan data sekunder. Data primer diperoleh dari observasi dan kuesioner terhadap 35 sampel orang yang tergabung dalam kelompok petani Kenanga Mulya, Desa Langon, Kecamatan Ponggok, Kabupaten Blitar. Jumlah sampel diperoleh dengan menggunakan rumus dari Taro Yemane atau Slovin (S. Riyanto \& Hatmawan, 2020:12) sebagai berikut:

Keterangan:

$$
\mathrm{n}=\mathrm{N} /\left(1+\mathrm{N}(\mathrm{e})^{2}\right)
$$

$$
\begin{array}{ll}
\mathrm{n} & =\text { Jumlah sampel } \\
\mathrm{N} & =\text { Jumlah populasi } \\
\mathrm{e} & =\text { Persen kelonggaran ketidaktelitian karena kesalahan pengambilan sampel yang masih dapat } \\
& \text { ditolerir sebesar 5\% }(0,05)
\end{array}
$$

Berdasarkan rumus diatas, diperoleh jumlah sampel sebagai berikut:

$$
\begin{gathered}
\mathrm{n}=38 /\left(1+57(0,05)^{2}\right) \\
\mathrm{n}=34,7 \\
\mathrm{n}=35
\end{gathered}
$$

Data sekunder diperoleh dari publikasi online pemerintah melalui website Badan Pusat Statistik (BPS) Kabupaten Blitar, Kabupaten Blitar Dalam Angka Tahun 2019-2021, Dinas Perindustrian dan Perdagangan Jawa Timur, dan Sistem Informasi Ketersediaan dan Perkembangan Harga Bahan Pokok Jawa Timur. Dalam penelitian ini, variabel terikat (dependen) berupa harga bahan pokok di Kabupaten Blitar sebelum dan selama pandemic Covid-19, sedangkan variabel bebas (independen) terdiri atas data jumlah anggota keluarga, usia, pendapatan, pengeluaran pangan, dan luas lahan sebelum dan selama pandemi Covid-19. Untuk menguji pengaruh antara variabel dependen dengan 5 variabel independen maka digunakan persamaan regresi linier berganda dengan metode Ordinary Least Square (OLS), uji keakuratan estimasi Best Linier Unbias Estimate (BLUE) yang meliputi: uji signifikansi pengaruh parsial (Uji T), uji 
signifikansi simultan F (Uji F), uji koefisien determinasi $\left(\mathrm{R}^{2}\right)$, dan uji asumsi klasik yang meliputi: uji heteroskedastisitas dan uji multikolinearitas dengan menggunakan aplikasi berupa stata. Berikut teknik analisa data yang dilakukan:

\section{Uji Regresi Linier Berganda}

$$
\mathrm{Y}=\beta 0+\beta 1 \log \mathrm{X} 1+\beta 2 \log \mathrm{X} 2+\beta 3 \log \mathrm{X} 3+\beta 4 \log \mathrm{X} 4+\beta 5 \log \mathrm{X} 5+\mathrm{e}
$$

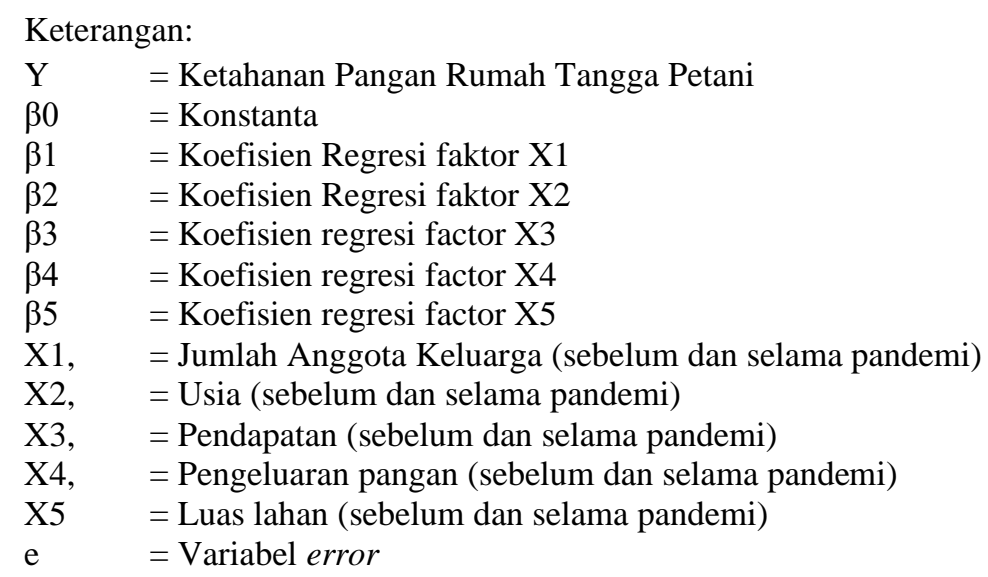

\section{Uji Signifikansi Pengaruh Parsial (Uji T)}

Uji-t ini bertujuan untuk melihat derajat pemaknaan setiap faktor bebas terhadap variabel terikat dalam model. Untuk pengujian ini digunakan uji t faktual, uji t dilakukan berdasarkan dinamika sebagai berikut: Dengan asumsi harga diri > 0,05, H0 diakui. Dengan asumsi harga diri < 0,05, H0 ditolak dan H1 diakui.

\section{Uji Signifikansi Simultan F (Uji F)}

Uji F dicoba buat memandang variabel independen mempengaruhi signifikan terhadap variabel dependen secara totalitas. Hasil dari uji ini pula bisa dilihat dalam tabel perhitungan regresi berganda, ialah dengan notasi ataupun simbol berbentuk ProbF. Apabila nilai ProbF lebih kecil dari 0, 05 hingga variabel independen secara simultan mempengaruhi signifikan terhadap variabel dependen.

\section{Uji Koefisien Determinasi $\left(\mathbf{R}^{2}\right)$}

Koefisien determinasi pada berbagai kekambuhan langsung digunakan untuk menentukan tingkat komitmen variabel otonom sekaligus terhadap variabel terikat. Atau sebaliknya untuk mengetahui seberapa besar kapasitas variabel otonom dalam mengklarifikasi variabel terikat. Nilai koefisien assurance dalam penelitian ini dilihat dari nilai R Square yang diubah.

\section{Uji Heteroskedastisitas}

Uji heteroskedastisitas bertujuan untuk menguji apakah pada model regresi terdapat ketidakseimbangan selisih dari residual persepsi yang satu dengan persepsi yang lain. Dalam hal nilai Prob. Chi Square $<0,05$ maka diduga terdapat masalah heteroskedastisitas. Dalam hal nilai Prob. Chi Square $>0,05$, diduga tidak ada tanda-tanda masalah heteroskedastisitas.

\section{Uji Multikolinearitas}

Tes ini ditentukan untuk menguji apakah ada hubungan yang ideal antara faktor otonom dalam model regresi. Multikolinearitas dalam penelitian ini dicoba menggunakan nilai Fluctuation Expansion Factor (VIF). Dalam hal nilai (VIF) 10 terjadi multikolinearitas antar faktor bebas. Dengan asumsi nilai (VIF) 10 tidak terjadi multikolinearitas antara faktor-faktor otonom dengan tujuan agar variabel tersebut dapat dimanfaatkan. 


\section{Definisi Operasional}

Berikut merupakan definisi operasioanl untuk memudahkan pembahasan dalam penelitian:

1. Ketahanan Pangan

Ketahanan pangan dalam penelitian ini merupakan kondisi tersedianya akses pangan bagi individual atau kelompok masyrakat untuk memenuhi kebutuhan pangan yang berguna untuk beraktifitas dan hidup sehat. Indikator dalam ketahanan pangan ini menggunakan data harga bahan pokok di Kabupaten Blitar Tahun 2019-2020 sebagai variabel dependen dengan satuan yang digunakan adalah rupiah.

2. Jumlah Anggota Keluarga

Jumlah anggota keluarga adalah banyaknya orang yang menjadi tanggungan dalam keluarga. Satuan yang digunakan pada variabel jumlah anggota keluarga adalah satuan orang. Dalam mengumpulkan data variabel jumlah anggota keluarga, peneliti menggunakan data kuisioner dan dinyatakan dalam bentuk angka.

3. Usia

Usia merupakan umur anggota keluarga responden yang diukur dengan melihat ulang tahun terakhir. Satuan yang digunakan dalam variable usia adalah tahun. Dalam pengumpulan data variabel usia, peneliti menggunakan data kuisioner dan dinyatakan dalam bentuk angka.

4. Pendapatan

Pendapatan merupakan jumlah penghasilan yang diterima oleh anggota keluarga dalam satu bulan. Pendapatan yang dimaksud dalam penelitian ini merupakan pendapatan yang diterima oleh anggota keluarga yang bekerja selama satu bulan. Satuan yang digunakan dalam variabel pendapatan adalah ribuan rupiah (Rp). Dalam pengolahan data, data pendapatan dibagi menjadi dua yaitu, pendapatan sebelum pandemi dan pendapatan selama pandemi. Dalam pengumpulan data variabel pendapatan, peneliti menggunakan data kuisioener dan dinyatakan dalam bentuk angka.

5. Pengeluaran

Pengeluaran konsumsi rumah tangga merupakan pengeluaran atas benda serta jasa oleh rumah tangga buat tujuan mengkonsumsi. Satuan yang digunakan dalam variabel pengeluaran adalah ribuan rupiah (Rp). Dalam pengolahan data, data pengeluaran dibagi menjadi dua yaitu, pengeluaran sebelum pandemi dan pengeluaran selama pandemi. Dalam pengumpulan data variabel pengeluaran, peneliti menggunakan data kuisioner dan dinyatakan dalam bentuk angka.

6. Luas lahan

Luas lahan merupakan areal lahan yang diusahakan petani yang dinyatakan dalam hektar (ha). Dalam pengolahan data, data luas lahan dibagi menjadi dua yaitu, luas lahan sebelum pandemi dan luas lahan selama pandemi. Dalam pengumpulan data variabel pengeluaran, peneliti menggunakan data kuisioner dan dinyatakan dalam bentuk angka.

\section{HASIL DAN PEMBAHASAN}

Uji Regresi Linier Berganda

Berikut hasil uji regresi linier berganda data penelitian sebelum dan selama adanya pandemi:

Tabel 1. Hasil Uji Regresi Linier Berganda Sebelum Pandemi

\begin{tabular}{llllllll}
\hline No & Variabel & Coef. & Std. Err. & $\mathbf{t}$ & $\mathbf{P}>$ & $\mathbf{9 5 \%}$ Conf & Interval \\
\hline 1. & $\begin{array}{l}\text { Jumlah } \\
\text { anggota }\end{array}$ & -55.75412 & 67.0929 & -0.83 & 0.413 & -192.9745 & 81.46628 \\
& & & & & & \\
2. & Keluarga & 5.445992 & 8.514859 & 0.64 & 0.527 & -11.96885 & 22.86083 \\
3. & Pendapatan & 0.4847916 & 0.1078975 & 4.49 & 0.000 & 0.2641164 & 0.7054668 \\
4. & Pengeluaran & -0.3299256 & 0.1221472 & -2.70 & 0.011 & -0.5797447 & -0.0801065 \\
5. & Luas lahan & -0.6710177 & 0.2371028 & -2.83 & 0.008 & -1.155947 & -0.1860881 \\
& Cons & 1726.187 & 651.4651 & 2.65 & 0.013 & 393.7915 & 3058.583 \\
\hline
\end{tabular}

Sumber: Data diolah, (2021)

Dari hasil perhitungan regresi berganda tersebut dapat kita buat model regresinya yaitu :

$Y=1726,107-55,75412 X_{1}+5,445992 X_{2}+0,4847916 X_{3}-0,3299256 X_{4}-0,6710177 X_{5}+e$ 
Irfansyah, H., Rahmawati, $F$.

Tabel 2. Hasil Uji Regresi Linier Berganda Selama Pandemi

\begin{tabular}{llllllll}
\hline No & Variabel & Coef. & Std. Err. & $\mathbf{t}$ & $\mathbf{P}>$ & $\mathbf{9 5 \%}$ Conf & Interval \\
& & & & & $|\mathbf{t}|$ & & \\
\hline 1. & $\begin{array}{l}\text { Jumlah } \\
\text { anggota }\end{array}$ & -2254.114 & 4467.114 & -0.50 & 0.618 & -11390.39 & 6882.159 \\
& & & & & & \\
2. & keluarga & & & & & & \\
3. & Pendapatan & 783.1412 & 513.1189 & 1.53 & 0.138 & -266.3048 & 1832.587 \\
4. & Pengeluaran & -18.66693 & 8.311842 & -2.25 & 0.033 & -35.66655 & -1.667302 \\
5. & Luas lahan & -37.33679 & 15.99708 & -2.33 & 0.027 & -70.05449 & -4.6191 \\
& Cons & 69680.48 & 46752.93 & 1.49 & 0.147 & -25940.01 & 165301 \\
\hline
\end{tabular}

Sumber: Data diolah, (2021)

Dari hasil perhitungan regresi berganda tersebut dapat kita buat model regresinya yaitu : $Y=69680,48-2254,114 X_{1}+783,1412 X_{2}+9,174441 X_{3}-18,66693 X_{4}-37,33679 X_{5}+e$

\section{Uji Signifikansi Parsial (Uji T)}

Tabel 3. Hasil Uji Signifikansi Parsial Sebelum Pandemi

\begin{tabular}{llllllll}
\hline No & Variabel & Coef. & Std. Err. & $\mathbf{t}$ & $\mathbf{P}>$ & $\mathbf{9 5 \%}$ Conf & Interval \\
& & & & & $|\mathbf{t}|$ & & \\
\hline 1. & $\begin{array}{l}\text { Jumlah } \\
\text { anggota }\end{array}$ & -55.75412 & 67.0929 & -0.83 & 0.413 & -192.9745 & 81.46628 \\
& & & & & & \\
2. & Usia & 5.445992 & 8.514859 & 0.64 & 0.527 & -11.96885 & 22.86083 \\
3. & Pendapatan & 0.4847916 & 0.1078975 & 4.49 & 0.000 & 0.2641164 & 0.7054668 \\
4. & Pengeluaran & -0.3299256 & 0.1221472 & -2.70 & 0.011 & -0.5797447 & -0.0801065 \\
5. & Luas lahan & -0.6710177 & 0.2371028 & -2.83 & 0.008 & -1.155947 & -0.1860881 \\
& Cons & 1726.187 & 651.4651 & 2.65 & 0.013 & 393.7915 & 3058.583 \\
\hline
\end{tabular}

Sumber: Data diolah, (2021)

Untuk data penelitian di atas untuk melihat variabel independen mana saja yang berpengaruh signifikan atau tidaknya terhadap variabel dependen dapat dilihat dari perhitungan $P>|t|$. Jika hasil dari $(P$ $>|\mathrm{t}|)<0.05$ maka variabel independent tersebut berpengaruh signifikan, begitupun sebaliknya. Dari hasil diatas maka dapat diketahui bahwa variabel yang signifikan ialah variabel X3 (pendapatan), X4 (pengeluaran pangan), dan X5 (luas lahan). Sedangkan untuk pengujian uji t selama pandemi dapat dilihat pada tabel berikut:

Tabel 4. Hasil Uji Signifikansi Parsial Selama Pandemi

\begin{tabular}{llllllll}
\hline No & Variabel & Coef. & Std. Err. & $\mathbf{t}$ & $\mathbf{P}\rangle$ & $\mathbf{9 5 \%}$ Conf & Interval \\
\hline 1. & $\begin{array}{l}\text { Jumlah } \\
\text { anggota }\end{array}$ & -2254.114 & 4467.114 & -0.50 & 0.618 & -11390.39 & 6882.159 \\
& & & & & & \\
2. & keluarga & 783.1412 & 513.1189 & 1.53 & 0.138 & -266.3048 & 1832.587 \\
3. & Pendapatan & 9.174441 & 10.92871 & 0.84 & 0.408 & -13.17728 & 31.52616 \\
4. & Pengeluaran & -18.66693 & 8.311842 & -2.25 & 0.033 & -35.66655 & -1.667302 \\
5. & Luas lahan & -37.33679 & 15.99708 & -2.33 & 0.027 & -70.05449 & -4.6191 \\
& Cons & 69680.48 & 46752.93 & 1.49 & 0.147 & -25940.01 & 165301 \\
\hline
\end{tabular}

Sumber: Data diolah, (2021) 
Untuk data penelitian di atas untuk melihat variabel independen mana saja yang berpengaruh signifikan atau tidaknya terhadap variabel dependen dapat dilihat dari perhitungan $P>|t|$. Jika hasil dari ( $P$ $>|\mathrm{t}|)<0.05$ maka variabel independen tersebut berpengaruh signifikan, begitupun sebaliknya. Dari hasil diatas maka dapat diketahui bahwa variabel yang signifikan ialah variabel X4 (pengeluaran pangan) dan X5 (luas lahan).

\section{Uji Signifikansi Simultan (Uji F)}

Tabel 5. Hasil Uji Signifikansi Simultan Sebelum Pandemi dan Selama Pandemi

\begin{tabular}{lllll}
\hline No. & Keterangan & Number of obs & F $(5,29)$ & Prob $>$ F \\
\hline 1. & Sebelum pandemi & 35 & 12.65 & 0.000 \\
2. & Selama pandemi & 35 & 3.03 & 0.0254 \\
\hline
\end{tabular}

Sumber: Data diolah, (2021)

Berdasarkan hasil dari uji $\mathrm{F}$ terhadap variabel sebelum pandemi tersebut menunjukkan bahwa nilai dari Prob $>$ F adalah 0,0000. Dimana hasil dari Prob $>$ F yaitu 0,0000 < 0,05 sehingga secara simultan ratarata jumlah anggota keluarga, usia, pendapatan, pengeluaran pangan, dan luas lahan berpengaruh signifikan terhadap tingkat ketahanan pangan. Sedangkan selama pandemic nilai Prob $>$ F adalah 0,0254. Dimana hasil dari Prob $>$ F yaitu 0,0254 < 0,05 sehingga secara simultan rata-rata jumlah anggota keluarga, usia, pendapatan, pengeluaran pangan, dan luas lahan berpengaruh signifikan terhadap tingkat ketahanan pangan.

\section{Koefisien Determinasi ( $\mathbf{U j i}^{\mathbf{2}}$ )}

Tabel 6. Hasil Uji R ${ }^{2}$ Sebelum Pandemi dan Selama Pandemi

\begin{tabular}{lllll}
\hline No. & Keterangan & Number of obs & R-squared & Adj R-squared \\
\hline 1. & Sebelum pandemi & 35 & 0.6856 & 0.6314 \\
2. & Selama pandemi & 35 & 0.3434 & 0.2302 \\
\hline
\end{tabular}

Sumber: Data diolah, (2021)

Berdasarkan hasil dari uji $\mathrm{R}^{2}$ terhadap variabel sebelum pandemi tersebut menunjukkan bahwa nilai dari R-squared adalah 0,6856 atau 68,56\%, sehingga kemampuan jumlah anggota keluarga, usia, pendapatan, pengeluaran pangan, dan luas lahan dalam menjelaskan tingkat ketahanan pangan sebesar $68,56 \%$ sisanya dijelaskan oleh variabel lain di luar model. Sedangkan selama pandemi nilai dari R-squared adalah 0,3434 atau 34,34\%, sehingga kemampuan jumlah anggota keluarga, usia, pendapatan, pengeluaran pangan, dan luas lahan dalam menjelaskan tingkat ketahanan pangan sebesar $34,34 \%$ sisanya dijelaskan oleh variabel lain di luar model.

\section{Uji Heterokedastisitas}

Tabel 7. Hasil Uji Heterokedastisitas Sebelum Pandemi dan Selama Pandemi

\begin{tabular}{cllc}
\hline No. & Keterangan & Chi2 (1) & Prob>chi2 \\
\hline 1. & Sebelum pandemi & 26.70 & 0.0000 \\
2. & Selama pandemi & 6.83 & 0.0090 \\
\hline
\end{tabular}

Sumber: Data diolah, (2021)

Berdasarkan hasil perhitungan uji heterokedastisitas tersebut, dapat dilihat bahwa hasil dari uji heterokedastisitas untuk variabel sebelum pandemi menunjukkan bahwa nilai dari Prob>chi2 adalah 0,0000 , yang hasil tersebut yaitu $0,0000<$ alpha $(0,05)$ sehingga tidak terdapat adanya heteokedastisitas atau varians dari error term konstan. Sedangkan selama pandemi menunjukkan bahwa nilai dari Prob>chi2 adalah 0,0090, yang hasil tersebut yaitu $0,0090<$ alpha $(0,05)$ sehingga tidak terdapat adanya heteokedastisitas atau varians dari error term konstan. 
Irfansyah, H., Rahmawati, F.

Uji Multikolinieritas

Tabel 8. Hasil Uji Multikolinieritas Sebelum Pandemi dan Selama Pandemi

\begin{tabular}{lll}
\hline No. & Keterangan & Mean VIF \\
\hline 1. & Sebelum pandemi & 1.49 \\
2. & Selama pandemi & 1.85 \\
\hline
\end{tabular}

Sumber: Data diolah, (2021)

Berdasarkan hasil perhitungan uji multikolinieritas tersebut, dapat dilihat bahwa hasil dari uji multikolinieritas untuk variabel sebelum pandemi menunjukkan bahwa nilai dari mean VIF adalah 1,49 dimana hasil tersebut yaitu 1,49 < 10 sehingga tidak ada multikolinieritas atau tidak terdapat korelasi tinggi antar variabel independen dalam model. Sedangkan selama pandemi menunjukkan bahwa nilai dari mean VIF adalah 1,85 dimana hasil tersebut yaitu $1,85<10$ sehingga tidak ada multikolinieritas atau tidak terdapat korelasi tinggi antar variabel independen dalam model.

\section{Pengaruh Jumlah Anggota Keluarga Terhadap Ketahanan Pangan Rumah Tangga Petani Pada Kelompok Tani Kenanga Mulya Desa Langon}

Variabel jumlah anggota keluarga pada saat sebelum pandemi dan selama pandemi menunjukkan hasil yang serupa. Pada masa sebelum pandemi, variabel jumlah anggota keluarga tidak berpengaruh signifikan terhadap tingkat ketahanan pangan rumah tangga petani. Hasil regresi menunjukkan variabel jumlah anggota keluarga memiliki nilai $\mathrm{P}>|\mathrm{t}| 0,413>0,05$ (alfa). Hal ini dapat terjadi mengingat rata-rata jumlah anggota keluarga berdasarkan 35 responden adalah 1-5 orang. Hal ini menunjukkan bahwa semakin besar jumlah anggota keluarga, maka semakin kecil peluang tercapainya ketahanan pangan rumah tangga. Selama pandemi, variabel jumlah anggota keluarga berpengaruh tidak signifikan terhadap tingkat ketahanan pangan rumah tangga petani. Hasil regresi menunjukkan variabel jumlah anggota keluarga memiliki nilai $\mathrm{P}>|\mathrm{t}|$ $0,618>0,05$ (alfa). Hal Ini dikarenakan jumlah anggota keluarga selama pandemi tidak mengalami perubahan atau tetap, yaitu rata-rata jumlah anggota keluarga berdasarkan 35 responden adalah 1-5 orang. Hal tersebut menunjukkan semakin besar jumlah anggota keluarga maka semakin kecil peluang tercapainya ketahanan pangan rumah tangga petani.

Hasil penelitian ini sesuai dengan penelitian yang dilakukan oleh Pramita Wahyu Adhi Saputro dan Yuli Fidayani (2020), Melia Anggraini, Wan Abbas Zakaria, dan Fembriarti Erry (2014), Ni Putu Ratih Pradnyadewi, Dwi Putra Darmawan, dan Gede Mekse Korri Arisena (2021), Robert Aidoo, James Osei Mensah, Thomas Tuffour (2015) yang menyatakan bahwa jumlah anggota keluarga tidak berpengaruh signifikan. Hal ini dikarenakan semakin banyak jumlah anggota keluarga semakin besar pula pengeluaran untuk konsumsi pangan. Dan semakin sedikit jumlah anggota keluarga maka semakin tinggi tingkat ketahanan pangannya

Hal ini tidak sama dengan penelitian yang dilakukan oleh Vizia Lukri Damayanti dan Rifki Khoirudin (2016) yang menunjukkan bahwa jumlah anggota keluarga berpengaruh signifikan terhadap ketahanan pangan keluarga. Hal ini karena dengan banyaknya anggota keluarga yang bekerja dapat membangun ketahanan pangan keluarga.

\section{Pengaruh Usia Terhadap Ketahanan Pangan Rumah Tangga Petani Pada Kelompok Tani Kenanga Mulya Desa Langon}

Faktor usia baik sebelum pandemi maupun selama pandemi menunjukkan hasil yang serupa. Sebelum pandemi, variabel usia tidak berpengaruh signifkan terhadap ketahanan pangan rumah tangga petani. Hasil regresi menunjukkan variabel usia memiliki nilai $P>|t| 0,527>0,05$ (alfa). Selama masa pandemi, variabel usia tidak berpengaruh signifikan terhadap ketahanan pangan keluarga petani. Hasil regresi menunjukkan variabel usia memiliki nilai $\mathrm{P}>|\mathrm{t}| 0,138>0,05$ (alfa). Hal ini berbeda dengan teori yang menunjukkan bahwa semakin dewasa usia seseorang maka produktifitasnya akan meningkat, hal ini diidentikkan dengan pemenuhan kebutuhan pangan. Perbedaan ini disebabkan karena responden yang menjadi contoh dalam penelitian ini memiliki usia 55-64 tahun sebesar 54\% yang menunjukkan bahwa usia tersebut berada dalam klasifikasi tidak produktif penuh.

Meskipun penelitian ini bertentangan dengan hipotesis, penelitian ini dikuatkan oleh penelitian yang dilakukan oleh Vizia Lukri Damayanti dan Rifki Khoirudin (2016), Ni Putu Ratih Pradnyadewi, Dwi Putra Darmawan, dan Gede Mekse Korri Arisena (2021), Robert Aidoo dan James Osei Mensah, Thomas Tuffour (2015) yang mengemukakan bahwa usia memiliki dampak negatif dan tidak signifikan terhadap ketahanan pangan. Namun berbanding terbalik dengan penelitian yang dilakukan oleh Jemal Abafita, Kyung-Ryang Kim (2014) yang menyatakan bahwa variabel usia berpengaruh positif dan signifikan terhadap ketahanan 
pangan. Dalam penelitian ini, contoh responden memiliki usia produktif yaitu 20-54 tahun, dimana semakin bertambah umur seseorang maka semakin tinggi tingkat produktifitasnya. Semakin tinggi produktifitasnya, maka semakin besar pendapatan yang diperoleh. Tingkat ketahanan pangan akan semakin tinggi jika pendapatan yang diperoleh besar.

\section{Pengaruh Pendapatan Terhadap Ketahanan Pangan Rumah Petani Pada Kelompok Tani Kenanga Mulya Desa Langon}

Variabel pendapatan pada saat sebelum pandemi dan selama pandemi menunjukkan hasil yang berbeda. Sebelum adanya pandemi variabel pendapatan berpengaruh signifikan terhadap tingkat ketahanan pangan rumah tangga petani. Hasil regresi menunjukkan bahwa variabel pendapatan memiliki nilai $\mathrm{P}>|\mathrm{t}|$ $0,000<0,05$ (alpha). Hal ini berarti, berapapun besaran pendapatan yang diperoleh, fokus utama dalam mengalokasikan pendapatanya adalah untuk kebutuhan pangan. Hal ini sesuai dengan teori ketersediaan pangan yang menjelaskan bahwa Pasokan pangan dalam rumah tangga mempengaruhi kuantitas Asupan makanan anggota keluarga. Semakin baik persediaan makanannya Keluarga dapat memenuhi semua kebutuhan nutrisi maka semakin baik pula tingkat ketahanan pangannya (Priswanti, 2004).

Sejalan dengan penelitian yang dilakukan oleh Wahyu Adhi Saputro dan Yuli Fidayani (2020), Vizia Lukri Damayanti dan Rifki Khoirudin (2016), Melia Anggraini, Wan Abbas Zakaria, dan Fembriarti Erry (2014), Isma Nur Amalia dan Trias Mahmudiono (2017), Ni Putu Ratih Pradnyadewi, Dwi Putra Darmawan, dan Gede Mekse Korri Arisena (2021), Katarzyna 'Zmija, Arlindo Fortes, Moses Nganwani Tia, Sandra ' $\mathrm{S}$ ' umane, Sylvester Nsobire Ayambila, Dariusz Zmija, Łukasz Satoła, Lee-Ann Sutherland (2020), Robert Aidoo, James Osei Mensah, Thomas Tuffour (2015) yang mengemukakan bahwa pendapatan berpengaruh signifikan terhadap ketahanan pangan rumah tangga petani. Hal tersebut dikarenakan ketika pendapatan semakin besar maka kerawanan pangan semakin rendah sehingga rumah tangga petai berada pada kondisi tahan pangan.

Sedangkan Selama pandemi variabel pendapatan berpengaruh tidak signifikan terhadap tingkat ketahanan pangan rumah tangga petani. Hasil regresi menunjukkan bahwa variabel pendapatan memiliki nilai $\mathrm{P}>|\mathrm{t}|$ 0,408 > 0,05 (alpha). Selama pandemi covid-19 rata-rata pendapatan masyarakat mengalami penurunan. Hal ini disebabkan karena selama pandemi ada berbagai faktor yang menekan kondisi petani, terutama soal tidak stabilnya harga barang-barang yang dibutuhkan untuk proses produksi seperti harga pupuk.

Penelitian ini sejalan dengan penelitian yang dilakukan oleh Cindy Aliciafahlia, Maleha, Yuprin A. D. (2019) yang menyatakan bahwa pendapatan berpengaruh tidak signifikan terhadap tingkat ketahanan pangan rumah tangga petani.

\section{Pengaruh Pengeluaran Pangan Terhadap Ketahanan Pangan Rumah Tangga Petani Pada Kelompok Tani Kenanga Mulya Desa Langon}

Variabel pengeluaran pangan pada saat sebelum pandemi dan selama pandemi menunjukkan hasil yang sama. Variabel pengeluaran pangan sebelum pandemi berpengaruh signifikan terhadap tingkat ketahanan pangan rumah tangga petani. Hasil regresi menunjukkan bahwa variabel pengeluaran pangan sebelum pandemi memiliki nilai $\mathrm{P}>|\mathrm{t}| 0,011<0,05$ (alpha). Sedangkan Selama pandemi variabel pengeluaran untuk kebutuhan pangan berpengaruh signifikan terhadap tingkat ketahanan pangan rumah tangga petani. Hasil regresi menunjukkan bahwa variabel pengeluaran selama pandemi memiliki nilai $\mathrm{P}>|\mathrm{t}| 0,033<0,05$ (alpha).

Hasil penelitian ini sejalan dengan penelitian yang dilakukan oleh Ni Putu Ratih Pradnyadewi, Dwi Putra Darmawan, dan Gede Mekse Korri Arisena (2021), Jemal Abafita, Kyung-Ryang Kim (2014) yang menunjukkan bahwa variabel pengeluaran berpengaruh signifikan terhadap ketahanan pangan rumah tangga petani. Hal ini dapat diartikan bahwa semakin tinggi pengeluaran rumah tangga untuk kebutuhan pangan maka tingkat ketahanan pangan rumah tangga juga semakin tinggi, sejalan dengan pendapatan yang diperoleh jika pendapatan tinggi, maka pengeluaran akan pangan juga semakin tinggi.

\section{Pengaruh Luas Lahan Terhadap Ketahanan Pangan Rumah Tangga Petani Pada Kelompok Tani Kenanga Mulya Desa Langon}

Variabel luas lahan pada saat sebelum pandemi dan selama pandemi menunjukkan hasil yang sama. Sebelum adanya pandemi variabel luas lahan berpengaruh signifikan terhadap tingkat ketahanan pangan rumah tangga petani. Hasil regresi menunjukkan bahwa variabel pendapatan memiliki nilai $\mathrm{P}>|\mathrm{t}| 0,008<$ 0,05 (alpha). Sedangkan selama pandemi variabel luas lahan berpengaruh signifikan terhadap tingkat 
ketahanan pangan rumah tangga petani. Hasil regresi menunjukkan bahwa variabel luas lahan memiliki nilai $P>|\mathrm{t}| 0,027<0,05$ (alpha).

Sejalan dengan penelitian yang dilakukan oleh Katarzyna 'Zmija, Arlindo Fortes, Moses Nganwani Tia, Sandra ' ${ }^{-}$' umane, Sylvester Nsobire Ayambila, Dariusz Zmija, Łukasz Satoła, Lee-Ann Sutherland (2020) yang mengemukakan bahwa luas lahan berpengaruh signifikan terhadap ketahanan pangan. Namun berbeda dengan penelitian yang dilakukan oleh Ni Putu Ratih Pradnyadewi, Dwi Putra Darmawan, dan Gede Mekse Korri Arisena (2021) yang menunjukkan bahwa variabel luas lahan berpengaruh tidak signifikan terhadap ketahanan pangan rumah tangga petani.

\section{KESIMPULAN}

Berdasarkan penelitian yang telah dilakukan dan pembahasan yang telah dikemukakan maka didapat kesimpulan sebagai berikut: Sebelum pandemi Covid-19, variabel jumlah anggota keluarga berpengaruh tidak signifikan terhadap tingkat ketahanan pangan rumah tangga petani, variabel usia berpengaruh tidak signifikan terhadap tingkat ketahanan pangan rumah tangga petani, variabel pendapatan berpengaruh signifikan terhadap tingkat ketahanan pangan rumah tangga petani, variabel pengeluaran berpengaruh signifikan terhadap tingkat ketahanan pangan rumah tangga petani, dan variabel luas lahan berpengaruh signifikan terhadap tingkat ketahanan panganrumah tangga petani. Sedangkan selama pandemi Covid-19, variabel jumlah anggota keluarga berpengaruh tidak signifikan terhadap tingkat ketahanan pangan rumah tangga petani, variabel usia berpengaruh tidak signifikan terhadap tingkat ketahanan pangan rumah tangga petani, variabel pendapatan berpengaruh tidak signifikan terhadap tingkat ketahanan pangan rumah tangga petani, variabel pengeluaran berpengaruh signifikan terhadap tingkat ketahanan pangan rumah tangga petani, dan variabel luas lahan berpengaruh signifikan terhadap tingkat ketahanan pangan rumah tangga petani.

\section{DAFTAR PUSTAKA}

Aidoo, R., \& Tuffour, T. (2015). Determinants Of Household Food Security In The Sekyere-Afram Plains District Of Ghana. 1st Annual International Interdisciplinary Conference, AIIC 2013, 24-26.

Aliciafahlia, C., Maleha, \& D, Y. A. (2019). Faktor-faktor yang Mempengaruhi Ketahanan Pangan Rumah Tangga di Kelurahan Habaring Hurung Kecamatan Bukit Batu Kota Palangkaraya. Journal Socio Economics Agricultural, 14(2), 40-47.

Amalia, I. N., \& Mahmudiono, T. (2017). Hubungan Pendapatan, Total Pengeluaran, Proporsi Pengeluaran Pangan dengan Status Ketahanan Rumah Tangga Petani Gurem (Studi di Desa Nogosari Kecamatan Rambipuji Kabupaten Jember). Amerta Nutrition, 1(2), 143.

Anonim. (2020). Update Perkembangan Covid-19 Kabupaten Blitar. Retrieved January 5, 2020, from https://tanggapcorona.blitarkab.go.id/

Badan Pusat Statistik Kabupaten Blitar. (2020). Luas Panen dan Produksi Padi di Kabupaten Blitar 2020. Berita Resmi Statistik, 2(16), 1-12.

Case, K. E. (2008). Prinsip-prinsip ekonomi jilid 1. Jakarta: Erlangga.

Damayanti, V. L., \& Khoirudin, R. (2016). Analisis Faktor - Faktor Yang Mempengaruhi Ketahanan Pangan Rumah Tangga Petani (Studi Kasus : Desa Timbulharjo, Sewon, Bantul). Jurnal Ekonomi \& Studi Pembangunan, 17(2).

Disperindag Jatim. (2020). Sistem Informasi Ketersediaan dan Perkembangan Harga Bahan Pokok di Jawa Timur (Komoditas Cabai Rawit). Siskaperbapo.Com. Retrieved from https://siskaperbapo.com/

Hery, S., \& Maulana, M. (2012). Luas Lahan Usaha Tani dan Kesejahteraan Petani: Eksistensi Petani Gurem dan Urgensi Kebijakan Reforma Agraria, 17-30.

Kim, K. (2014). Determinants of Household Food Security in Rural Ethiopia: An Empirical Analysis. Journal of Rural Development / Nongchon-Gyeongje, 37(2), 1-29.

Meilia, A., Zakaria, W. A., \& Prasmatiwi, F. E. (2014). Ketahanan Pangan Rumah Tangga Petani Kopi di 
Kabupaten Lampung Barat. Jiia, 2(2), 133-141.

Pasaribu, R. B. F. (2008). Ketahanan pangan nasional, (7), 531-569.

Putu, N., Pradnyadewi, R., Darmawan, D. P., Mekse, G., Arisena, K., Pertanian, F., \& Udayana, U. (2021). Ketahanan Pangan Rumah Tangga Petani di Subak Sembung Pada Saat Pandemi Covid-19, 9(1), 346-356.

Riawati, Rosnita, and R. Y. (2016). Karakteristik Internal Dan Karakteristik Eksternal Petani Kelapa Sawit Di Desa Buluh Rampai Kecamatan Seberida Kabupaten Indragiri Hulu. 28, 3(2), 99-102.

Riyanto, S., \& Hatmawan, A. A. (2020). Metode Riset Penelitian Kuantitatif Penelitian Di Bidang Manajemen, Teknik, Pendidikan dan Eksperimen. Sleman: Deepublish.

Saputro, W. A., \& Fidayani, Y. (2020). Faktor-Faktor Yang Mempengaruhi Ketahanan Pangan Rumah Tangga Petani di Kabupaten Klaten. Agrica (Jurnal Agribisnis Sumatera Utara) Vol.13 No.2/Oktober 2020, 13(2), 115-123.

Saukah, A. (2017). Pedoman Penulisan Karya Ilmiah. Tugas Akhir, Skripsi, Tesis, Disertasi, Artikel, Makalah, dan Laporan Penelitian.

Sukmaningrum, A., \& Imron, A. (2017). Memanfaatkan Usia Produktif Dengan Usaha Kreatif Industri Pembuatan Kaos Pada Remaja Di Gresik. Jurnal Paradigma, 5(3), 1-6.

Suryana, Nia Kurniaish, Said Usman, A., \& Ariani. (2014). Agroekosistem Lahan Kering ( Kajian Sosiologis di Kota Tarakan ). Magrobis Jurnal, 14(2), 27-38.

Undang-undang Republik Indonesia Nomor 18 Tahun 2012 Tentang Pangan. (2012). , 66(3), 37-39.

Utari, E. A. T. and Zulfaridatulyaqin, S. M. (2020) 'Kontribusi Sektor Pertanian Subsektor Tanaman Pangan terhadap PDRB pada Kabupaten Banjar (Pendekatan PDRB Hijau)', Ecoplan, 3(2), pp. 5565. doi: 10.20527/ecoplan.v3i2.69.

WHO. (2020). Coronavirus Disease Ikhtisar kegiatan, 19, 1-13.

Widiantoro, W. E. (2020). Kecamatan Ponggok Dalam Angka 2020. Blitar: BPS Kabupaten Blitar.

Żmija, K., Fortes, A., Tia, M. N., Šūmane, S., Ayambila, S. N., Żmija, D., Satoła, Ł., et al. (2020). Small farming and generational renewal in the context of food security challenges. Global Food Security, 26. 